\title{
Game Motorik : Aritmatika Step
}

\author{
Arif Purnomo $^{1} \quad$ Endah Sudarmillah $^{2}$ \\ Program Studi Informatika, Universitas Muhammadiyah Surakarta \\ Email: ${ }^{1}$ arifpurnomo886@gmail.com, ${ }^{2}$ endah.sudarmillah@ums.ac.id
}

\begin{abstract}
Abstrak: Perkembangan Game di dunia semakin pesat, termasuk di Indonesia. Game sering digunakan sebagian orang sebagai sarana hiburan ataupun pendidikan anak-anak, dewasa, pria maupun wanita. Seringnya seseorang memaikan Game khususnya anak-anak membuat mereka melupakan belajar dan tumbuh kembang motorik. Penelitian ini bertujuan untuk merangsang minat anak belajar matematika melalui Game edukasi dan meransang tumbuh kembang motorik anak. Game ini dibuat menggunakan aplikasi platform 2D dengan dancepad sebagai kontroler pada Game dengan menggunakan metode System Development Life Cycle (SDLC) dengan model waterfall. Hasil penelitian ini berupa Game motorik aritmatika step. Pada Game ini terdapat 4 level dan memiliki soal-soal yang berbeda pada setiap levelnya. Pengujian Game dilakukan dengan uji Black box dan metode System Usability Scale (SUS), dengan 30 responden menghasilkan score SUS sangat baik yaitu 79,5 sehingga Game dapat diterima.
\end{abstract}

Kata Kunci: Game, edukasi, matematika, 2D, motorik, dancepad

\begin{abstract}
The development of Games in the world is growing rapidly, including in Indonesia. Games are often used by some people as a means of entertainment or education for children, adults, men and women. Often someone plays Games, especially children, making them forget about learning and motor development. This research aims to stimulate children's interest in learning mathematics through educational Games and stimulate children's motor development. This Game was made using application platfrom $2 D$ with dancepad as a controller in the Game using the System Development Life Cycle (SDLC) method with the waterfall model. The results of this research are step arithmetic motor Games. In this Game there are 4 levels and have different questions at each level. Game testing is done by using the Black box test and the System Usability Scale (SUS) method, with 30 respondents producing a very good SUS score of 79.5 so that the Game can be accepted
\end{abstract}

Keywords: Game, education, mathematics, 2D, motoric, dancepad

Perkembangan Game di dunia semakin pesat, termasuk di Indonesia. Game memegang fungsi yang cukup penting sebagai sarana hiburan atau juga Pendidikan atau latihan bagiorang tua, muda, pria maupun wanita, apalagi anak-anak [1]. Game digital adalah Game yang populer pada saat ini.

Game berjenis edukasi untuk memancing minat belajar anak terhadap materi pelajaran sambal ber-"Game", sehingga dengan perasaan senang diharapkan siswa bisa lebih mudah memahami materi pelajaran yang disajikan. Jenis ini sebenarnya lebih mengacu kepada isi dan tujuan Game, bukan jenis yang sesungguhnya. Game merupakan seuah tools yang efektif untuk mengajar karena mengandung prinsip-prinsip pembelajaran dan Teknik instruksional yang efektif digunakan dalam penguatan pada level-level yang sulit [2].

Game saat ini selain sebagai hiburan juga sebagai media mengajar yaitu melalui Game edukasi, matematika merupakan mata pelajaran yang sudah dikenal sejak kecil, karena matematika berguna dalam segala aspek kehidupan operasi dasar dalam matematika antara lain kali $(x)$, bagi $(\div)$, tambah $(+)$, kurang $(-)$. Matematika akan lebih mudah diajarkan pada anak sejak usia dini. Seperti kata pepatah, belajar di waktu kecil bagai mengukir di atas batu, belajar sesudah dewasa serupa mengukir di atas air. Begitu juga halnya ketika belajar matematika yang memang akan lebih efektif jika mulai beajar matematika dari kecil karena di usia itulah anak- 
anak bisa dengan mudah mengingat dalam belajar menghitung [3].

Saat ini belum banyak Game yang menggunakan motorik sebagai alat penunjang dalam Game. Motorik merupakan salah satu factor yang sangat berpengaruh terhadap potensi gerak dalam keterampilan olah tubuh dan

mobilitas hidup seseorang. Kemampuan motorik halus merupakan keterampilan yang sangat penting untuk menunjang semua pembelajaran yang ada. Game edukasi dapat memudahkan pengajar atau pembimbing anakanak dalam mengajarkan sebuah pelajaran yang dapat diingat dan mudah dipahami oleh anak.

Salah satunya dengan menggunakan Gamemaze yang dapat meningkatkan perkambangan motorik anak dan melatih kontrol otot kecil, koordinasi mata, jari dan merangsang anak untuk lebih minat dalam belajar [4], akan tetapi belum banyak Game sekarang yang menerapkan motorik dan edukasi di dalamnya untuk proses pembelajaran anak.

Beberapa penelitian sejenis tentang Game edukasi matematika sudah peneliti kumpulkan dirangkum kedalam meta analis serta dibuat fishbone. dalam fishbone terdapat beberapa metode penelitian yaitu metode SDLC $(2,5,8)$, waterfall $(4,6)$, kuantitatif $(3,7), \operatorname{MDLC}(9,10)$ dan perancangan prototipe (1).

Tujuan dari penelitian sejenis yaitu membentuk pemain dalam melatih ketelitian, kecepatan dan kemampuan dalam menghitung, atau bisa dilihat pada nomor 3,4,5,6. Menarik minat anak untuk tidak bosan mempelajari matematika dengan Game edukasi [6], atau bisa dilihat pada nomor $1,7,8,9,10$.mempermudah mengajar dan tumbuh kembang motorik anak [4].

Subjek dari penelitian terdahulu yang sejenis semua menggunakan subjek anak-anak sebagai subjek karena pada usia tersebut anak mudah mengingat apa yang mereka pelajari. Penelitian ini diharapkan dapat sebagai media edukasi anak dalam belajar matematika agar anak tertarik untuk belajar, juga dapat melatih tumbuh kembang motorik pada anak. Alur fishbone dapat dilihat pada gambar 1 dibawah ini.

\section{METODE PENELITIAN}

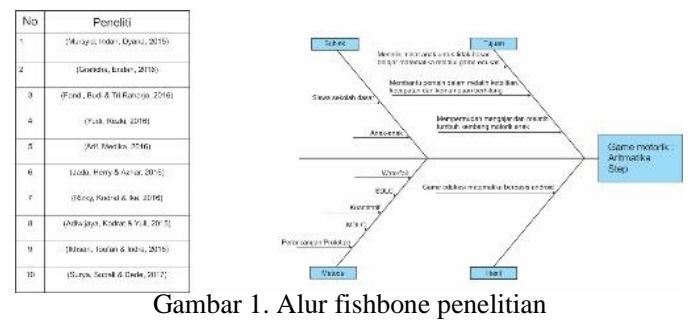

Adapun metode yang digunakan yaitu menggunakan metode SDLC (System Development Life Cycle) dengan model Waterfall. Dimana berisi rangkaian aktifitas proses yang teratur dan disajikan dalam proses yang terpisah [7], rangkaian aktifitas tersebut adalah Analisa kebutuhan, desain, coding dan pengujian seperti pada gambar 2 berikut :

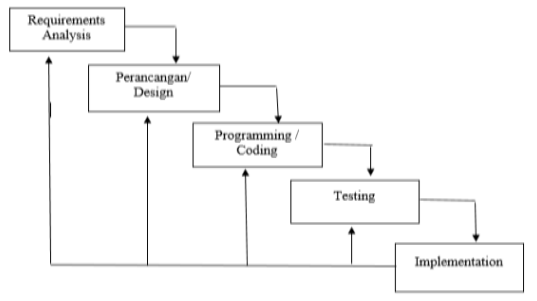

Gambar 2. Flowcat alur penelitian

Tahapan-tahapan pembuatan aplikasi Game edukasi (penjelasan gambar 2) meliputi:

\section{Requirements Analysis}

Dalam langakah ini merupakan analisa terhadap kebutuhan sistem. Pengumpulan data dalam tahap ini bisa melakukan sebuah penelitian, wawancara atau studi literatur. Seseorang peneliti akan menggali informasi sebanyak banyaknya dari pengguna sehingga akan tercipta sebuah aplikasi / program yang bisa melakukan tugas-tugas yang diinginkan oleh pengguna tersebut.

\section{Kebutuhan Fungsional Storyline Game aritmatika step}

Game edukasi motorik dengan nama aritmatika step ini bercerita tentang pemain yang menjawab soal matematika yang terdiri dari 4 level yaitu penjumlahan, pengurangan, perkalian, pembagian. Game ini memiliki 3 button kanan, kiri dan atas dan terdapat timer dan skor. Game ini memiliki 4 level, pada level 1 berisi soal tentang pertambahan, level 2 berisi tentang pengurangan, level 3 berisi tentang perkalian, dan level 4 berisi tentang pembagian, masing-masing 
level mempunyai kesulitan tersendiri untuk menjawab soal. Terdapat timer dan skor pada setiap levelnya, jika tidak bisa melewati level pertama maka akan mengulangi level tersebut dengan soal yang sama, jika terdapat kesalahan saat menjawab soal maka aka nada pemberitahuan pada setiap soal dan level.

\section{User}

User merupakan pengguna yang memainkan Game, dalam penelitian ini yang berperan sebagai user yaitu anak-anak dengan kategori sekolah dasar kelas 1 dan 2.

\section{Genre}

Genre merupakan bentuk, kriteria, atau jenis dalam Game. Dalam penelitian ini genre dalam Game ini yaitu Game edukasi.

\section{Interaksi}

Interaksi dalam Game merupakan gambaran fungsi yang harus dikerjakan pada system yang bersangkutan. Gambaran perencanaan Game edukasi yang meliputi fungsional system yaitu:

- System dapat menampilkan soal matematika.

- $\quad$ System dapat mengacak soal matematika.

- $\quad$ System dapat memaikan musik.

- System dapat menampilkan skor.

- System dapat menampilkan timer.

\section{Kebutuhan Non Fungsional}

Kebutuhan non fungsional merupakan tahapan pengembang menganalisa sumber daya yang digunakan dalam perancangan Game edukasi, yang terdiri dari perangkat lunak (software) dan perangkat keras (hadware).

Tabel 1. Kebutuhan non fungsional

\begin{tabular}{|l|l|}
\hline \multicolumn{1}{|c|}{ Hadware } & \multicolumn{1}{|c|}{ Software } \\
\hline a.Computer / & $\begin{array}{l}\text { a.Windows / } \\
\text { Linux Ubuntu } \\
\text { b.Step pad }\end{array}$ \\
& b.Google Crome \\
& c.Corel Draw \\
& d.Construct 2 \\
\hline
\end{tabular}

\section{Perancangan/Design}

Saat medesain permainan untuk anak, hal penting yang harus dipertimbangkan adalah mengenali dan menyesuaikan user interface dengan karakter dan psikologi pengguna. Karena itu, akan terlihat apakah Game ini sesuai atau tidak untuk kelompok usia anak-anak [8]Proses Design akan menterjemahkan syarat kebutuhan ke sebuah perancangan perangkat lunak yang dapat diperkirakan sebelum diimplementasikan. Proses ini berfokus pada use case diagram, activity diagram, storyline, dan storyboard.

\section{Use Case}

Analisis use case menggambarkan merespresentasikan interaksi yang dapat terjadi antara user (pengguna atau mesin lain) dengan system [9]. Pada diagram use case untuk pemain seperti tampak pada gambar 3, pemain dapat melihat soal, menjawab soal, dan mendapatkan skor.

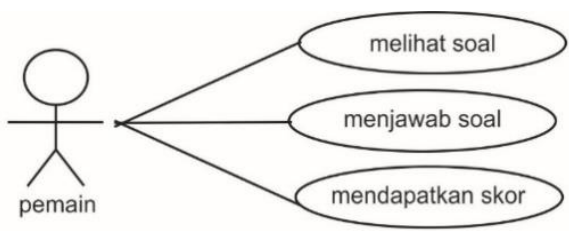

Gambar 3. Gambar use case diagram pemain

Pada diagram use case seperti yang tampak pada gambar 4, admin dapat membuat perhitungan skor, desain antarmuka, menulis kode (coding), debug dan memberikan efek.

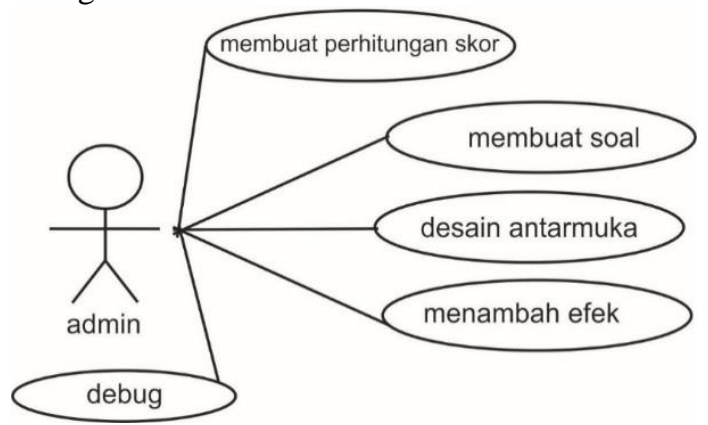

Gambar 4. Gambar use case diagram admin

\section{Activity Diagram}

Activity diagram (diagram aktifitas) adalah sebuah diagram yang menjelaskan logika procedural dan jalur kerja program aplikasi yang dibuat baik dari sisi user (pengguna) maupun dari sisi sistem[10] . Mulai dari awal, pemilihan tombol mulai yang kemudian system akan 
meneruskan pemain ke scere "tampilan awal", kemudian meneruskan lagi ke scere "play" kemudian system akan memulai permainan, pemain akan melihat soal yang diberikan terhadap system dan pemain harus menjawabnya, kemudian system akan mengecek apakah jawaban benar atau salah jika jawaban benar maka system akan memberikan skor dan jika salah maka system akan menampilakan tulisan salah pada sistem, jika waktu yg diberikan sistem sudah habis maka Game akan otomatis mengulangi pada soal yg belum terjawab, activity diagram pada Game ini bisa dilihat pada gambar 5 dibawah.

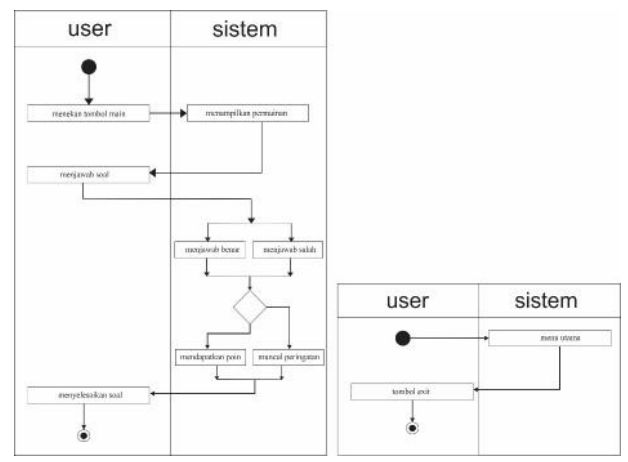

Gambar 5. Activity diagram

\section{Coding}

Tahap merupakan tahap mentranslasikan desain kedalam bentuk program. Aplikasi yang digunakan dalam pembuatan Game ini yaitu Construct 2, dengan cara menyusun blok-blok kode pada setiap button yang ada. Construct 2 adalah aplikasi untuk membuat Game 2 dimensi berbasis HTML-5, itu tidak memerlukan keterampilan dalam pemrograman [11]

\section{HASIL DAN PEMBAHASAN}

\section{Pengujian}

Pengujian perangkat lunak adalah teknik yang paling sering digunakan untuk memverifikasi dan memvalidasi kualitas perangkat lunak [12]. Pengujian dilakukan untuk mengetahui keefektifan Game edukasi yang telah dibuat dalam penggunaannya sebagai media pembelajaran matematika [13], serta mengetahui fungsi-fungsi berjalan dengan baik sesuai apa yang diinginkan. Pengujian yang dilakukan pada penelitian ini menggunakan metode blackbox dan usability. Pengujian blackbox (adalah pengujian berdasarkan spesifikasi persyaratan dan tidak memeriksa kode, pengujian blackbox dilakukan berdasarkan persyaratan yang tidak dapat diprediksi dapat dengan mudah didentifikasi dan dapat diatasi [14]. Berdasarkan sitasi penelitian ini menggunakan kuisioner sebagai pengujian usabilitynya.

\section{Hasil Tampilan Game}

\section{Pengenalan Menu utama}

Pengenalan menu utama pada Game ini terdapat 4 menu yaitu main, pengaturan, petunjuk \& keluar. Pengenalan menu utama bisa dilihat pada gambar 6.

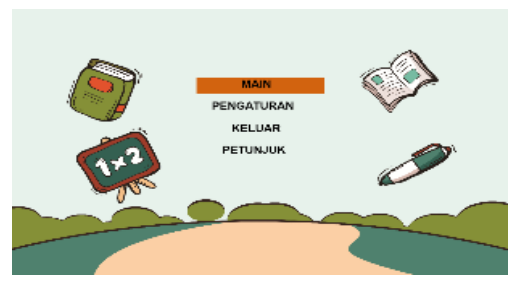

Gambar 6. Menu utama

Menu awal gambar 6 saat Game ini dibuka akan muncul menu seperti gambar 6 yang berisikan daftar menu main, pengaturan, keluar dan petunjuk.

\section{Menu Main}

Menu main pada Game ini terdapat 4 level di tiap levelnya terdapat beberapa soal yang berbeda sesuai dengan levelnya. Menu main bisa dilihat pada gambar 7.

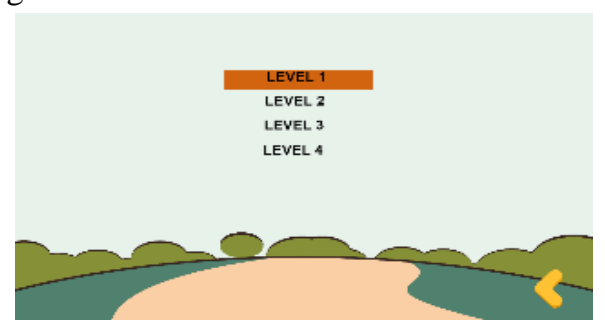

(a)

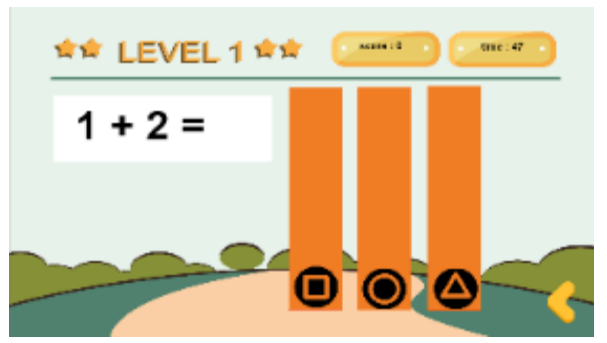

(b) 


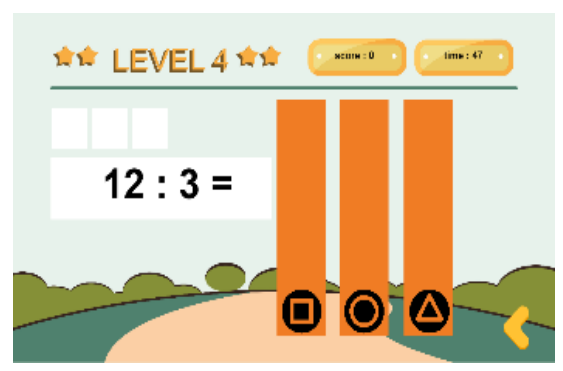

(c)

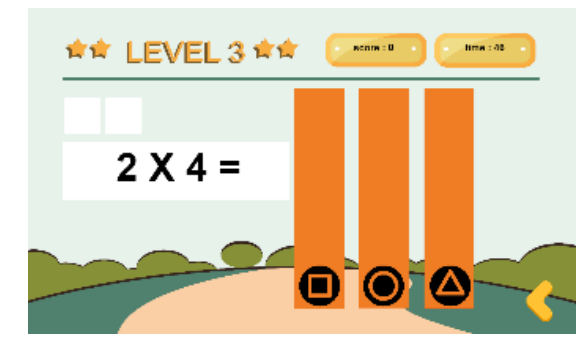

(d)

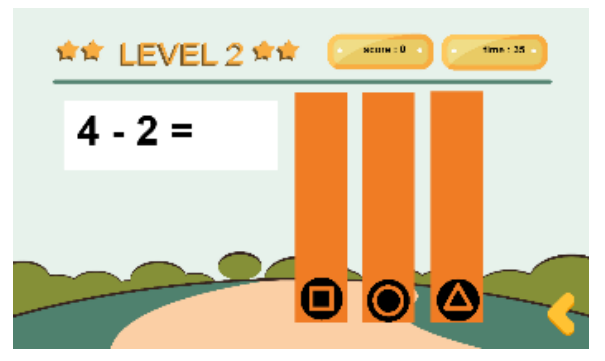

(e)

Gambar 7. Menu main (a), level 1 (b), level 2 (c), level 3 (d), level 4 (e)

Menu main gambar 7(a) berisi level dalam Game yang terdiri dari 4 level yang masing-masing level memiliki kesulitan tersendiri. Level 1 gambar 7(b) berisi soal pertambahan, level 2 gambar 7(c)berisi tentang pengurangan, level 3 gambar 7(d) berisi tentang perkalian, dan level 4 gambar 7(e) berisi tentang pembagian.

\section{Menu Pengaturan}

Menu pengaturan pada Game ini berisi tentang mengatur musik pada Game. Menu pengaturan gambar 8 berisikan perintah untuk mematikan dan menghidupkan musik dalam Game, ada 2 perintah dalam menu pengaturan yaitu on untuk menghidupkan musik dan off untuk mematikan musik.

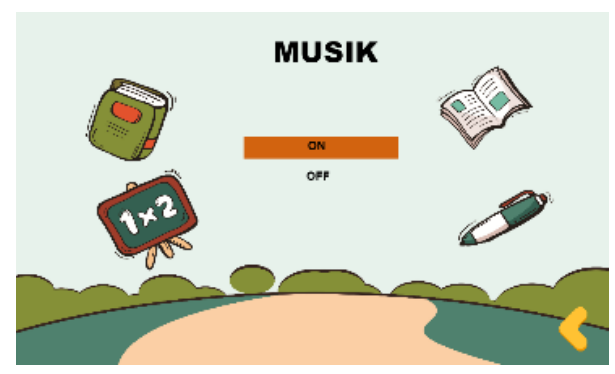

Gambar 8. Menu pengaturan

\section{Menu Keluar}

Menu keluar pada Game ini berisi tentang perintah untuk keluar dari Game. Menu keluar bisa dilihat pada gambar 9 .

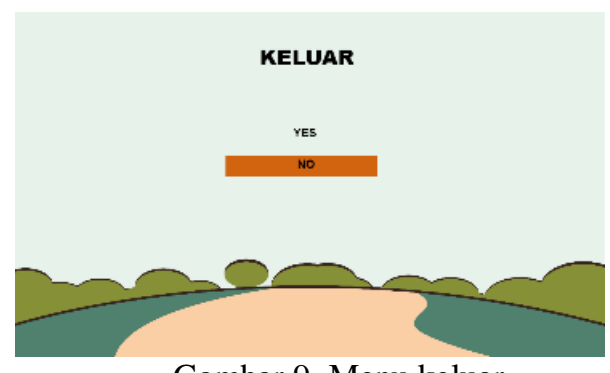

Gambar 9. Menu keluar

Menu keluar gambar 9 berisikan perintah untuk keluar dari Game atau kembali memainkan Game, ada 2 perintah yaitu yes untuk keluar dari Game dan no untuk kembali ke menu utama untuk memainkan Game.

\section{Menu Petunjuk}

Menu pentunjuk pada Game ini berisikan tentang sebuah petunjuk untuk memainkan Game ini. Menu petunjuk bisa dilihat pada gambar 10.

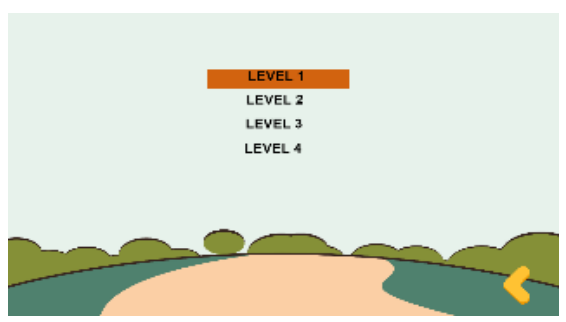

Gambar 10. Menu petunjuk

Menu pentunjuk gambar 10 berisikan tentang petunjuk tentang kontrol pada Game ini dan sedikit penjelasan tentang isi soal pada setiap level. 


\section{Uji Black box}

Metode Black Box memungkinkan perekayasa perangkat lunak mendapatkan serangkaian kondisi input yang sepenuhnya menggunakan semua persyaratan fungsional untuk suatu program[15]. Dari menu yang telah diuji menyatakan hasil diterima. Peneliti sudah melakukan uji perbandingan perhitungan hasil manual dan hasil aplikasi dengan mencoba input 10 data secara acak hanya menghasilkan sedikit error yaitu sekitar $1 \%$ - 2\%. Uji black box aplikasi edukasi gizi dapat dilihat pada Tabel 2.

Tabel 2. Uji black box

\begin{tabular}{|c|c|c|c|c|}
\hline no & Item & Skenario & Output yg diharapkan & Hasil \\
\hline \multirow[t]{4}{*}{1} & Menu utama & Klik tombol play & Masuk ke menu game level & ok \\
\hline & & $\begin{array}{ll}\text { Klik } & \text { tombol } \\
\text { nengaturan }\end{array}$ & Masuk ke menu pengaturan & ok \\
\hline & & 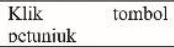 & Masuk ke petunjuk game & ok \\
\hline & & klik keluar & Masuk ke menu keluar & ok \\
\hline \multirow[t]{2}{*}{2} & $\begin{array}{l}\text { Menu } \\
\text { peneaturan }\end{array}$ & Klik on & Memainkan musik & \\
\hline & & klik off & Mematikan musik & ok \\
\hline \multirow[t]{4}{*}{3} & $\begin{array}{l}\text { Memainkan } \\
\text { game }\end{array}$ & Menjawab soal & $\begin{array}{l}\text { Game akan menampilkan opsi } \\
\text { dari jawaban }\end{array}$ & ok \\
\hline & & Menjawab benar & $\begin{array}{l}\text { Game akan melanjutkan ke soal } \\
\text { berikutnva }\end{array}$ & ok \\
\hline & & Meniawab salah & Muncul peringatan salah & ok \\
\hline & & $\begin{array}{ll}\begin{array}{l}\text { Klik } \\
\text { selaniutnya }\end{array} & \text { level } \\
\end{array}$ & Lanjut ke level berikutnya & ok \\
\hline \multirow[t]{3}{*}{4} & Menu betuniuk & Klik petuniuk & Menambilkan vetuniuk øame & ok \\
\hline & Menu keluar & Klik va & Keluar game & ok \\
\hline & & Klik tidak & Kembali ke menu utama & ok \\
\hline
\end{tabular}

\section{Uji Usability}

System Usability Scale (SUS) adalah salah satu metode uji pengguna yang menyediakan alat ukur yang "quick and dirty" dan dapat diandalkan. Diaplikasikan dengan menggunakan 10 pertanyaan berbentuk kuisioner yang diikuti dengan 5 opsi jawaban untuk setiap pernyataan, mulai dari sangat setuju hingga sangat tidak setuju. Uji usability menggunakan metode SUS menguji sistem dengan 30 responden kategori orang dewasa. SUS adalah alat ukur yang valid dan dapat diandalkan, dengan membuat perbandingan skor yang di capai pada sistem.

Untuk mengetahui seberapa baik dan tidaknya suatu program dapat dilihat peringkat score pada gambar 12 dibawah ini sebagai tolak ukur pengujian System Usability Scale (SUS).

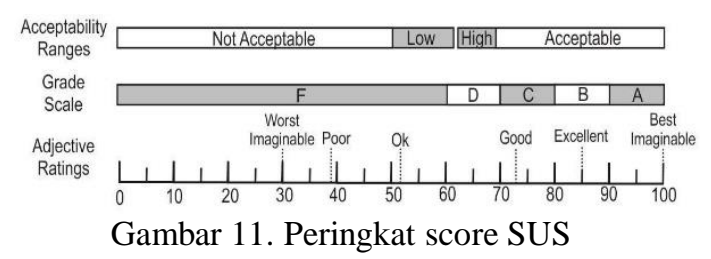

Gambar 11. Peringkat score SUS
Hasil perhitungan uji usability SUS dapat dilihat pada Tabel 3 dan grafik SUS score tiap responden dapat dilihat pada Gambar 12.

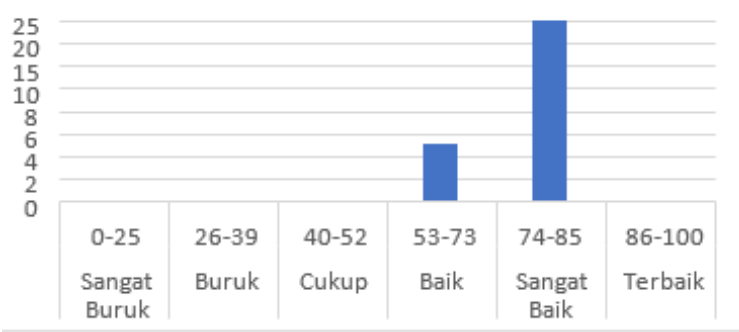

Gambar 12. Grafik Score SUS Tiap

Responden

Tabel 3. Hasil pengujian usability



Keterangan kode:

P1: Aplikasi sangat disukai dan akan menggunakanya berkali-kali

P2: Aplikasi terlalu rumit digunakan

P3: Aplikasi mudah digunakan

P4: Membutuhkan bantuan orang lain dalam menggunakan aplikasi

P5: Bagian-bagian aplikasi dapat digunakan dengan baik

P6: Aplikasi membingungkan

P7: Orang lain akan belajar menggunakan aplikasi ini dengan sangat cepat atau mudah 
P8: Aplikasi ini tidak praktis atau sulit digunakan P9: Bisa menggunakan aplikasi ini

P10: Perlu belajar banya untuk menggunakan aplikasi ini

1: Sangat tidak setuju

2: Tidak setuju

3: Ragu

4: Setuju

5: Sangat Setuju

Hasil perhitungan uji usability SUS pada Tabel 3, menghasilkan jumlah score SUS yaitu 2542,5. Kemudian mencari nilai rata-rata dari jumlah score SUS, yang dapat dilihat pada Persamaan 1.

$$
\begin{aligned}
& \text { Nilai rata }- \text { rata }=\sum_{i=1}^{n} \frac{x_{i}}{N} \\
& \text { dimana: } \\
& x_{i}: \text { Jumlah score SUS } \\
& N \text { : Jumlah responden }
\end{aligned}
$$

Rata Jumlah Score SUS $=\frac{2542,5}{30}=84,75$

Nilai rata - rata jumlah score SUS mendapatkan hasil 84,75 yang dapat dilihat pada Persamaan 2, kemudian dilihat seberapa baik sistem aplikasi dengan tolak ukur peringkat score SUS. Game motorik : Aritmatika Step menujukan hasil sangat baik (excellent) dan dapat diterima (acceptable).

\section{KESIMPULAN}

Berdasarkan penelitian sebelumnya, tidak diragukan lagi bahwa Game edukasi dapat menunjang proses Pendidikan. Game edukasi unggul dalam beberapa aspek jika dibandingkan dengan metode pembelajaran konvensional [16]. Game aritmatika step ini dibuat agar mempermudah dalam proses belajar mengajar sehingga anak lebih tertarik belajar matematika melalui Game aritmatika step. Game aritmatika step ini selain bisa mempermudah proses belajar mengajar diharapkan juga bisa merangsang perkembangan motorik pada anak. Game ini berisi juga tentang gimana caranya mempermudah belajar pertambahan, pengurangan, perkalian dan pembagian dengan berbagai soal yg diberikan membuat anak lebih kreatif dalam berfikir dan menjawab soal.

Pengujian Game aritmatika step ini mendapatkan hasil yang baik. Uji black box fungsi-fungsi sudah berjalan sesuai dengan apa yang di harapkan. Uji usability juga menyatakan bahwa aplikasi mendapat nilai rata-rata score SUS sangat baik yaitu 84,75 , sehingga aplikasi ini dapat diterima.

\section{DAFTAR PUSTAKA}

[1] G. Benedic Guit, "Game Edukasi Matematika Untuk Anak Sekolah Dasar Berbasis Android," Inform.

Mulawarman J. Ilm. Ilmu Komput., vol. 10, no. 2, pp. 1-78, 2015.

[2] J. A. Yustin and M. A. Irwansyah, "Rancang Bangun Aplikasi Game Matematika Menggunakan Construct 2," J. Sist. dan Teknol. Inf., vol. Vol. 1, no. 1, pp. 1-5, 2016.

[3] M. Adiwijaya, K. I. S, and Y. Christyono, "Perancangan Game Edukasi Platform Belajar Matematika Berbasis Android Menggunakan Construct 2," J. Transient, vol. Vol.4, no. 1, pp. 128-133, 2015.

[4] G. \& E. S. Kusuma, "Pengembangan Permainan Labirin untuk Membantu Perkembangan Motorik Anak," J. Fak. Tek. Univ. Khairun, vol. 03, no. 2354 8924, pp. 46-89|, 2016.

[5] F. Ahmad Rizal, B. Suyanto, T. Raharjo Yudantoro, J. Elektro, and P. Negeri Semarang, "Aplikasi Game Edukasi Matematika Dengan Konsep Aritmatika Anak Berbasis Android," J. Pendidik. Mat., pp. 45-50.

[6] S. A. Pramuditya, M. S. Noto, and D. Syaefullah, "Game Edukasi Rpg Matematika," J. EduMa, vol. Vol.6, no. 1, pp. 77-84, 2017.

[7] E. Sudarmilah and P. A. Wibowo, "khazanah informatika Aplikasi Augmented Reality Game Edukasi untuk Pengenalan Organ Tubuh Manusia," pp. 20-25, 2016.

[8] E. Sudarmilah, A. Susanto, R. Ferdiana, and N. Ramdhani, "Developing A Game for Preschoolers : What Character, Emotion and Reward will Tend to Hack Preschoolers ?," pp. 2-5, 2016.

[9] A. Vega Vitianingsih, "Game Edukasi Sebagai Media Pembelajaran Pendidikan Anak Usia Dini,” vol. 1, 2016.

[10] \& D. Supriyono, Nur, Ardhiyatama, Sudarmillah, "Rancang bangun aplikasi 
pembelajaran hadis untuk perangkat mobile berbasis android," vol. 8 , no. 2 , pp. 907-920, 2014.

[11] E. Sudarmilah, R. Ferdiana, L. Edi, A. Susanto, and N. Ramdhani, "Tech Review : Game Platform for Upgrading Counting Ability on Pre school Children," 2013.

[12] D. E. P. d.shao, S. Khurshid, a case for white-box testing using declarative specification poster abstract. 2007.

[13] D. P. Hermawan and D. Herumurti, "Efektivitas penggunaan Game edukasi berjenis puzzle, rpg dan puzzle rpg sebagai sarana belajar matematika," pp. 195-205.

[14] J. Nindra, S. \& DOndeti, Black box testing techniques, internasional journal of embeded systems and application. 2012.

[15] A. Rouf, "Pengujian perangkat lunak dengan menggunakan metode white box dan black box," pp. 1-7, 2012.

[16] R. Nuqisari, E. Sudarmilah, and F. Komunikasi, "Pembuatan Game Edukasi Tata Surya dengan Construct 2 Berbasis Android," J. Emit., vol. 19, no. 02, pp. 90-96, 2019. 